\title{
Contrast enhanced ultrasound (CEUS) in Pregnancy: Is this the last frontier for microbubbles?
}

\author{
Kontrastverstärkter Ultraschall (CEUS) in der Schwangerschaft: \\ Eine letzte Grenze für den Einsatz von Microbubbles?
}

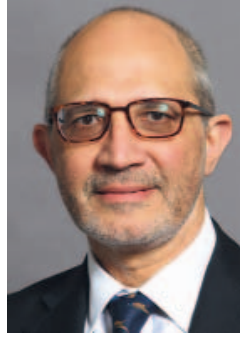

Paul S. Sidhu

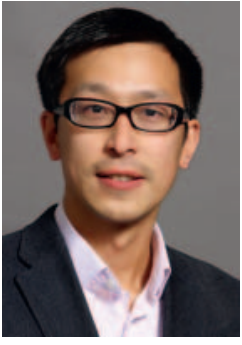

Dean Y. Huang

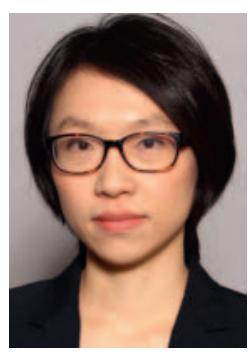

Cheng Fang
Correspondence

Paul S. Sidhu

Department of Radiology, King's College Hospital

Denmark Hill, London SE5 9RS, United Kingdom

paulsidhu@nhs.net
Bibliography

DOI https://doi.org/10.1055/a-0964-9827

Published online: 2020

Ultraschall in Med 2020; 41: 8-11

(c) Georg Thieme Verlag KG, Stuttgart · New York

ISSN 0172-4614
In this issue a group of researchers present their experience using the ultrasound contrast agent (UCA) SonoVue ${ }^{\mathrm{TM}}$ (Bracco SpA, Milan) in a series of pregnant women, assessing and characterising incidental focal liver lesions with magnetic resonance (MR) imaging as the reference standard [1]. The authors have assessed six pregnant women using contrast enhanced ultrasound (CEUS) over a period of time, each with focal liver lesions not characterised on the baseline ultrasound examination, two of which were malignant, and without any recorded detrimental effect to the foetus. The presence of malignancy, unexpected in both cases, substantially altered patient management and confirmation of benign disease allowed for continued normal pregnancy management. The one case of Echinococcal disease maintained a normal pregnancy and delivery, with definitive management instituted post-delivery. All the patients avoided the potential of ionising radiation from a computed tomography (CT) examination, and underwent an MR examination without contrast enhancement (gadolinium). The authors argue that as the UCA is truly intra-vascular the UCA should therefore theoretically be of no hazard to the foetus during a CEUS examination, and this technique should be more widely applied during pregnancy to avoid imaging with MR and potentially $C T$, both with contrast agents that may have a deleterious effect in the foetus.

The utility of CEUS in characterising focal liver lesions is well established as an accurate and cost-effective technique, both in adult and paediatric patients, well tolerated, repeatable and nonhazardous to the patient [2-6]. The ability to deploy this imaging technique in pregnancy, although not likely to be required often to assess focal liver lesions, allows for reassurance of the patient and physician when an incidental liver lesion is encountered. The technique of CEUS, comfort for the patient and ability to provide an immediate diagnosis is an important aspect of the CEUS examination, particularly as the physician attending the examination is able to convey the result immediately; nearly all incidental focal liver lesions are benign.

A CEUS examination may be useful in other scenarios in pregnancy. Although pregnancy is a physiological state of "wellness" and it is unlikely that there will be a need to image any further than the developing foetus, only rarely are other abdominal organs imaged, and then only if the patient is symptomatic. A more common indication for imaging the pregnant patient is in the presence of infective renal disease, a relatively common complication during pregnancy, occasionally resulting in pyelonephritis and abscess formation. Baseline ultrasound will identify changes to the kidney, and identify the possibility of focal pyelonephritis or abscess formation, requiring further medical intervention. Here, the addition of a UCA will better define these abnormalities [7]. The presence of renal pelvicalyceal dilatation in pregnancy is not frequently managed with a percutaneous nephrostomy, but presents a dilemma for the physician. If intervention is required with an obstructed kidney, how can this be performed with minimal ionising radiation? The ability to perform the entire percutaneous nephrostomy procedure under ultrasound guidance is 
helpful, but often not feasible, necessitating the use of fluoroscopy with the attendant ionising radiation. The ability to add to the baseline ultrasound examination and to perform a CEUS examination safely would be advantageous. The intravenous application of UCA allows the safe and rapid cannulation of the dilated pelvicalyceal system [8] and insertion of a nephrostomy drainage catheter, even if the system is not prominently dilated [9]. This can be followed by a UCA catheter injection (intra-cavitary CEUS) to demonstrate the correct positioning of the drainage tube, without the need for fluoroscopy $[10,11]$.

Is this a remarkable pioneering event or are the authors risking the health of the foetus? It is likely that a number of CEUS procedures have been undertaken in the presence of an unidentified pregnancy, but this is not known. The use of a UCA in pregnancy is not a new application, others have demonstrated the utility in specific scenarios in humans with different UCA over the last few years $[1,12-14]$. The manufacturer of SonoVue ${ }^{\mathrm{TM}}$ states in their documentation accompanying the agent that there is no available clinical data on its use in pregnancy, although animal studies do not indicate harmful effects to the pregnancy, embryonal/foetal development, parturition or postnatal development [15]. The United States Food and Drug Administration (FDA) package insert (2017) states that there is no data on the use of Lumason ${ }^{\mathrm{TM}}$ in pregnant women to inform any drug associated risks. In contrast, the European Medicines Agency summary of product characteristics (2018) advises as a precautionary measure, that it is preferable to avoid the use of SonoVue ${ }^{\mathrm{TM}}$ during pregnancy [16]. Therefore, there is no explicit statement on the contraindication of using Lumason ${ }^{\mathrm{TM}} /$ SonoVue ${ }^{\mathrm{TM}}$ in pregnancy by the manufacturer or by the regulatory authorities.

Is there evidence to support the lack of toxicity of UCA treatment in pregnancy? In one experimental study, no UCA (noncommercial agent) was observed in the foetus or umbilical vessels when placental flow was assessed in rats [17]. Furthermore, in experimental rat studies it appears SonoVue ${ }^{\mathrm{TM}}$ does not affect the permeability of the placental barrier, with no leakage of molecules observed [17]. The plugging of spiral arteries in the placenta has been previously investigated using another agent, Definity ${ }^{\top M}$ (Lantheus Medical Imaging, Billerica, MA) [18] with no reported deleterious effects. Another agent Levovist ${ }^{\mathrm{TM}}$ (Schering, Berlin) was also used successfully to observe twin-twin transfusion [13]. It is encouraging that a prospective, multicentre, non-randomised, open-label clinical trial with SonoVue ${ }^{\mathrm{TM}}$ is planned to assess placental perfusion in early pregnancy by quantifying intervillous space perfusion during the first-trimester at three different gestational ages (8, 11 and 13 weeks) [19].

In summary, there is no evidence that the UCA SonoVue ${ }^{\mathrm{TM}}$ crosses the placental barrier to affect the well-being of the foetus, with ongoing studies assessing the integrity of the placental vascular component. The advantage of CEUS in assessing multiple areas of the body safely is well documented, to avoid ionising radiation, in often vulnerable adult and paediatric patients. Often the alternative, MR imaging, is useful, but cumbersome and expensive. In pregnancy, it would seem that a CEUS examination is an ideal tool to problem solve and provide optimal patient and foetal clinical management.

\section{Kontrastverstärkter Ultraschall (CEUS) in der Schwangerschaft: Eine letzte Grenze für den Einsatz von Microbubbles?}

In dieser Ausgabe präsentiert eine Forschergruppe ihre Erfahrungen mit dem Ultraschallkontrastmittel (UCA) SonoVue ${ }^{\mathrm{TM}}$ (Bracco SpA, Mailand) bei einer Serie von Schwangeren zur Bewertung und Charakterisierung von zufällig entdeckten fokalen Leberveränderungen mit einer Magnetresonanztomografie (MRT) als Referenzstandard [1]. Die Autoren haben 6 schwangere Frauen mit kontrastverstärktem Ultraschall (CEUS) über einen bestimmten Zeitraum hinweg untersucht. Alle hatten fokale Leberläsionen, die bei der Basisuntersuchung nicht weiter charakterisiert wurden; 2 davon waren maligne und ohne nachweislich schädliche Auswirkung auf den Fötus. Das Auftreten von Malignomen, die in beiden Fällen unvorhergesehen waren, führte hierbei zu einer erheblichen Veränderung des Patientenmanagements. Bei Nachweis eines gutartigen Geschehens wurde das Management der Schwangerschaft wie üblich fortgeführt. In 1 Fall mit Echinokokkose wurde die Schwangerschaft bis zur Geburt normal fortgeführt und die spezifische Behandlung erst nach der Entbindung eingeleitet. Bei allen Patienten wurde wegen der potenziellen Strahlenbelastung keine Computertomografie (CT), sondern stattdessen eine MRT-Untersuchung ohne Kontrastverstärkung (Gadolinium) durchgeführt. Die Autoren argumentieren, dass durch die intravaskuläre Gabe von UCA während einer CEUS-Untersuchung theoretisch keine Gefahr für den Fötus bestünde. Somit sollte diese Methode in der Schwangerschaft breitere Anwendung finden, um bildgebende Verfahren wie MRT oder sogar CT zu vermeiden, die beide Kontrastmittel mit potenziell schädlicher Wirkung auf den Fötus einsetzen.

Der Einsatz von CEUS als genaue und kostengünstige Technik ist bei der Charakterisierung von fokalen Leberläsionen sowohl bei Erwachsenen als auch bei pädiatrischen Patienten gängig, gut verträglich, wiederholbar und ungefährlich für den Patienten [2-6]. Die Möglichkeit, dieses bildgebende Verfahren in der Schwangerschaft einzusetzen, was sicher nicht häufig zur Beurteilung von fokalen Leberläsionen nötig ist, ist eine beruhigende Option für Patient und Arzt, sollte eine Leberläsion nebenbefundlich festgestellt werden. Die Techniken des CEUS, die Schonung des Patienten und die Möglichkeit der Sofortdiagnose sind wichtige Aspekte, die für die CEUS-Untersuchung sprechen, insbesondere dadurch, dass der behandelnde Arzt die Diagnose sofort stellen und übermitteln kann, denn fast alle zufällig entdeckten fokalen Leberveränderungen sind gutartig.

Eine CEUS-Untersuchung kann auch bei anderen Schwangerschaftskomplikationen nützlich sein. Grundsätzlich ist eine Schwangerschaft ein physiologischer Zustand des „Wohlbefindens“ und es ist meist nicht notwendig, andere Bilder aufzunehmen als die vom sich entwickelnden Fötus. Nur selten werden darüber hinaus die Bauchorgane dargestellt, und das nur, wenn beim Patienten Symptome vorliegen. Eine geläufige Indikation für die Bildgebung bei Schwangeren sind Infektionen der Niere, einer relativ häufig auftretenden Schwangerschaftskomplikation, die vereinzelt zu Pyelonephritis und Abszessbildung führt. Der Basisultraschall erkennt Veränderungen an der Niere und diagnostiziert eine mög- 
liche Pyelonephritis oder Abszessbildung, was weitere medizinische Interventionen erfordert. Hier werden diese Anomalien durch die zusätzliche Anwendung von UCA exakter diagnostiziert [7]. Bei Dilatation des Nierenbeckenkelchsystems in der Schwangerschaft wird manchmal eine perkutane Nephrostomie durchgeführt; diese stellt aber für den Arzt ein Dilemma dar. Wenn der Eingriff bei Nierenstauung erforderlich ist, kann dieser auch unter minimaler Strahlenbelastung durchgeführt werden? Die Option, die gesamte perkutane Nephrostomie unter Ultraschallkontrolle durchzuführen, ist hilfreich, aber häufig nicht durchführbar, und erfordert somit den Einsatz der Fluoroskopie mit der entsprechenden Strahlenbelastung. Die Möglichkeit, CEUS ergänzend zur Basisultraschalluntersuchung sicher durchzuführen, wäre von Vorteil. Die intravenöse UCA-Gabe ermöglicht die sichere und schnelle Kanülierung des erweiterten Nierenbeckenkelchsystems [8] und die Anlegung eines Nephrostomie-Drainagekatheters, auch wenn das System nicht markant dilatiert ist [9]. Anschließend kann eine UCA-KatheterInjektion (intrakavitäre CEUS) durchgeführt werden, um die korrekte Positionierung des Drainageschlauchs ohne Einsatz der Fluoroskopie darzustellen [10, 11].

Kann man dies als bemerkenswerte Pionierarbeit sehen oder gefährden die Autoren damit die Gesundheit des Fötus? Es ist durchaus möglich, dass vielfach CEUS-Untersuchungen durchgeführt wurden, ohne dass man von einer bestehenden Schwangerschaft wusste, aber das ist nicht genau zu eruieren. Die Anwendung von UCA in der Schwangerschaft ist nicht neu; andere haben in den letzten Jahren beim Menschen den Nutzen unterschiedlicher UCA bei spezifischen Fragestellungen gezeigt [1, 12-14]. Der Hersteller von SonoVue erklärt in seiner Begleitdokumentation, dass es keine klinischen Daten zur Anwendung in der Schwangerschaft gibt, obwohl im Tierversuch keine Hinweise auf schädliche Auswirkungen auf die Schwangerschaft, die embryonale/fetale Entwicklung, den Geburtsverlauf oder die postnatale Entwicklung gefunden wurden [15]. Die Packungsbeilage der „United States Food and Drug Administration“ (FDA) (2017) besagt, dass es für die Anwendung von Lumason ${ }^{\mathrm{TM}}$ bei schwangeren Frauen in Bezug auf mögliche medikamentenassoziierte Risiken keine Daten gibt. Dagegen wird in der Zusammenfassung der Produkteigenschaften der Europäischen Arzneimittelagentur (2018) darauf hingewiesen, dass der Einsatz von SonoVue während der Schwangerschaft vorsorglich zu vermeiden ist [16]. Somit gibt es weder durch den Hersteller noch durch die Zulassungsbehörden eine eindeutige Stellungnahme in Bezug auf Kontraindikationen bei Anwendung von Lumason/SonoVue in der Schwangerschaft.

Gibt es eine Evidenz dafür, dass der Einsatz von UCA in der Schwangerschaft unbedenklich ist? In einer experimentellen Studie zur Beurteilung des plazentaren Flusses bei Ratten konnte UCA (nichtkommerzieller Wirkstoff) weder im Fötus noch in den Umbilikalgefäßen beobachtet werden [17]. Darüber hinaus zeigt sich in experimentellen Studien mit Ratten, dass SonoVue keinen Einfluss auf die Permeabilität der Plazentaschranke hat und dass keine austretenden Moleküle beobachtet wurden [17]. Das Plugging der Spiralarterien der Plazenta wurde zuvor mit einem anderen Agens, Definity ${ }^{\mathrm{TM}}$ (Lantheus Medical Imaging, Billerica, MA), untersucht [18], ohne dass schädliche Wirkungen berichtet wurden. Ein weiteres Mittel, Levovist ${ }^{\mathrm{TM}}$ (Schering, Berlin), wurde ebenfalls erfolgreich zur Beobachtung des fetofetalen Transfusionssyndroms eingesetzt [13]. Es ist ermutigend, dass eine prospektive, multizentrische, nichtrandomisierte, open-label klinische Studie mit SonoVue geplant ist, um die Plazentaperfusion in der Frühgravidität zu beurteilen, wobei die Perfusion im intervillösen Raum im ersten Trimester in 3 verschiedenen Schwangerschaftswochen $(8,11$ und 13) quantifiziert wird [19].

Zusammenfassend lässt sich sagen, dass es keine Evidenz gibt, dass das UCA SonoVue die Plazentaschranke passiert und somit das Wohl des Fötus beeinträchtigt. Derzeit gibt es laufende Studien, welche die Integrität der Plazentagefäße bewerten. Der Vorteil von CEUS bei der sicheren Beurteilung vieler Körperregionen ist gut dokumentiert, um bei oft vulnerablen erwachsenen und pädiatrischen Patienten eine Strahlenbelastung zu vermeiden. Die Alternative, eine MRT-Untersuchung, ist häufig sinnvoll, aber umständlich und teuer. In der Schwangerschaft scheint die CEUS-Untersuchung die Idealmethode zur Abklärung und zum optimalen klinischen Management von Patientin und Fötus zu sein.

\section{References}

[1] Schwarze V, Marschner C, Negrúo de Figueiredo G et al. Single-center study: evaluating the diagnostic performance and safety of contrast-enhanced ultrasound (CEUS) in pregnant women to assess hepatic lesions. Ultraschall in Med 2019 Jul 30. doi:10.1055/a-0973-8517 [Epub ahead of print]

[2] Claudon M, Dietrich CF, Choi BI et al. Guidelines and good clinical practice recommendations for contrast enhanced ultrasound (CEUS) in the liver - update 2012. Ultraschall in Med 2013; 34: 11-29

[3] Seitz K, Strobel D, Bernatik T et al. Contrast-enhanced ultrasound (CEUS) for the characterization of focal liver lesions prospective comparison in clinical practice: CEUS vs. CT (DEGUM Multicenter Trial). Ultraschall in Med 2009; 30: 383-389

[4] Seitz K, Bernatik T, Strobel D et al. Contrast-enhanced ultrasound (CEUS) for the characterization of focal liver lesions in clinical practice (DEGUM Multicenter Trial): CEUS vs. MRI - a prospective comparison in 269 patients. Ultraschall in Med 2010; 31: 492-499

[5] Jacob J, Deganello A, Sellars ME et al. Contrast enhanced ultrasound (CEUS) characterization of grey-scale sonographic indeterminate focal liver lesions in paediatric practice. Ultraschall in Med 2013; 34: 529-540

[6] Sidhu PS, Cantisani V, Deganello A et al. Role of contrast-enhanced ultrasound (CEUS) in paediatric practice: An EFSUMB position statement. Ultraschall in Med 2017; 38: 33-43

[7] Fontanilla T, Minaya J, Cortes $C$ et al. Acute complicated pyelonephritis: contrast-enhanced ultrasound. Abdom Imaging 2012; 37: 639-646

[8] Huang DY, Yusuf GT, Daneshi M et al. Contrast-enhanced US guided Interventions: Improving success rate and avoiding complications using US contrast agents. Radiographics 2017; 37: 652-664

[9] Liu BX, Huang GL, Xie XH et al. Contrast-enhanced US-assisted percutaneous nephrostomy: A technique to increase success rate for patients with nondilated renal collecting system. Radiology 2017; 285: 293-301

[10] Daneshi M, Yusuf GT, Fang C et al. Contrast-enhanced ultrasound (CEUS) nephrostogram: utility and accuracy as an alternative to fluoroscopic imaging of the urinary tract. Clin Radiol 2019; 74: 167. e9-167

[11] Sidhu PS, Cantisani V, Dietrich CF et al. The EFSUMB guidelines and recommendations for the clinical practice of contrast-enhanced ultrasound (CEUS) in non-hepatic applications: Update 2017 (Short Version). Ultraschall in Med 2018; 39: 154-180

[12] Denbow ML, Blomley MJ, Cosgrove DO et al. Ultrasound microbubble contrast angiography in monochorionic twin fetuses. Lancet 1997; 349: 773 
[13] Denbow ML, Welsh AW, Taylor M] et al. Twin fetuses: intravascular microbubble US contrast agent administration - early experience. Radiology 2000; 214: 724-728

[14] Liu D, Yang M, Wu Q. Application of ultrasonography in the diagnosis and treatment of cesarean scar pregnancy. Clinica Chimica Acta 2018; 486: 291-297

[15] Bracco. LUMASON (sulfur hexafluoride lipid-type A microspheres) for injectable suspension, for intravenous use or intravesical use. Full Prescribing Information. Monroe Township, NJ: Bracco Diagnostics Inc., December 2016. https://imaging.bracco.com/sites/braccoimaging. com/files/technica_sheet_pdf/us-en-2017-01-04-spc-lumason.pdf. Accessed December 9, 2019

[16] European Medicines Agency. SonaVue. Summary of product characteristics, 25 May 2018. https://www.ema.europa.eu/en/documents/prod uct-information/sonovue-epar-product-information_en.pdf. Accessed December 9, 2019

[17] Hua X, Zhu LP, Li R et al. Effects of diagnostic contrast-enhanced ultrasound on permeability of placental barrier: A primary study. Placenta 2009; 30: 780-784

[18] Roberts VH], Morgan TK, Bednarek P et al. Early first trimester uteroplacental flow and the progressive disintegration of spiral artery plugs: new insights from contrast-enhanced ultrasound and tissue histopathology. Hum Reprod 2017; 32: 2382-2393

[19] Bertholdt C, Eszto ML, Tournier M et al. Assessment of uteroplacental vascularisation in early first-trimester pregnancy with contrast-enhanced ultrasound and 3D power Doppler angiography: protocol for a prospective, cross-sectional, multicentre and non-randomised open study (“HOPE Study”). BMJ Open 2019; 9: e030353 